\title{
PASTORAL AND MISSIONARY EXIGENCIES IN THE URBAN PARISH
}

\author{
Răzvan Brudiu*
}

\begin{abstract}
The Christian pastoral and mission have always played an important role in the culture and civilisation worldwide. The mission and the ecclesiastic are inseparable. Through His Sacrifice and Resurrection, Christ, as Pastor, gives life, communion, and love. In the same way, the priest is a pastor, due to his role of fulfilling the Holy Mysteries, re-enacting the act of Christ giving Himself for the life of the people. The priest is a pastor in his work of fulfilling the Holy Sacraments, which are the bread of the Church. In a confused contemporary society, priests do not have the capacity of totally embracing the elements that represent the complexity of the urban parish. Still, the pastoral consciousness imposes and charges them to find pastoral and missionary themes, programmes, and strategies that are stringently required. The mutations of urban religious communities are multiple and unpredictable, both from a psychological and an ecclesiastical point of view. They are determined not only by economic, social, and political conditions, but also by the understanding of religion as an individual option, or as a neutral intellectual luggage. This is why the profile of the urban parish presents characteristics and tendencies that are overlapping, dispersed, and difficult to integrate. Transforming the Church into religion may be seen as individualising belief, asceticism, and the cult. Belief is perverted in individual convictions, asceticism into individual morals, and the cult into individual duty. The correct convictions, the allegiance to moral commandments, and the consequence of fulfilling the obligations of the cult, are sufficient to ensure the deliverance of the individual. The desire of excessive urbanism contain neither the ideas of collectivities, community, body of communion relations constituted to the Eucharist dinner, nor the coparticipation to its fulfilling, the search for deliverance through the change of
\end{abstract}

* $\mathrm{PhD}$, "1 Decembrie 1918" University, Faculty of Orthodox Theology, Alba Iulia, Romania. 
modus vivendi by passing from the natural instinct of egoism to the renouncement to the self and loving the other.

Keywords: urban parish, priest, society, sermon, Eucharist, pastoral mission.

\section{The consolidation of the parochial community}

The parish is the local institutional reality of the Church, it represents the "edifying [of] the body of Christ" (Ephesians 4.12) an ideal that remains the supreme objective of the Christian pastoral and mission. Orthodoxy has the unique privilege of mission and Christian testimony in a traditional Christian society with solid and durable elements in these directions: divine cult, sacred music, sacred art, iconography ${ }^{1}$.

Christian mission aims at imprinting the seal of the liturgy and the Philocalia onto the existence, at transposing it into a liturgical and sacramental, baptistismal and Eucharistic rhythm, for the renewal of man and of the world, while waiting for the Kingdom of God as the Kingdom of the Holy Trinity, a foretaste of which we have in the Church $^{2}$.

The Church is "the body of Christ" (I Corinthians 12.27), the union and the unity of the believers in the Holy Ghost, in the Godly and adored humanity of the living Christ. Christ and the Church are in an inseparable and indissoluble unity. On the Day of Pentecost, the adored human nature of Christ returns to the world, after His ascension to the uncreated heaven of the sun of the Trinitarian Godhead, for the presence of Christ to be continued within the believers. However, it is now a different presence, one in the Holy

${ }^{1}$ Ion Bria, Regenerarea misiunii creştine în contextul urban, in "Relevanţa operei Părintelui Profesor Ion Bria pentru viața bisericească și socială actuală”, Sibiu, Publishing House: Universitatea "Lucian Blaga", 2010, p. 41.

${ }^{2}$ Ioan Ică jr., Misiune şi mărturie creştină fată de prozelitismul religios care este o contramărturie creştină, in "Pastorație și misiune în Biserica Ortodoxă", Galaţi, Publishing House: Episcopia Dunării de Jos, 2001, p. 34. 
Ghost. Christ returns within the Holy Ghost, in order to be the place of meeting and union for those saved in and through $\mathrm{Him}^{3}$.

The reality that puts Christ at the centre of the parochial community is expressed and achieved through a liturgical act that takes place towards the end of the Liturgy. It is the gathering of the Holy Gifts in the Holy Chalice, after the Holy Communion, when the priest gathers in the Chalice everything that is on the holy disk, except for the Agnet, i.e. the parts for the Holy Virgin, the angels, the Saints etc. Inside the Holy Chalice, the individual body of Christ becomes one with His communion body. The community of believers in Christ is now completely gathered in the Holy Chalice. The unity of the believers in Christ is achieved in the Church, where Christ is an icon of the unity of the Persons in the Holy Trinity ${ }^{4}$.

The Church may not confine itself to remaining a mere agency providing religious services in the territory. We need to start again living the city in a pastoral and missionary manner, around the bishop, according to the Christian tradition in the first centuries. Thus, the individual parochial realities do not disappear, but aquire new dimensions, being inserted in a common corpus.

The switch from the pastoral rhythm of the rural environment to the rhythm of the technological revolution in the urban society has provoked many changes for the believers. The contemporary urban parish has lost its identity and coherence, due to the mass migration of population from rural to urban areas, or from one urban area to another. Parishes in the large urban agglomerations today, parishes with anonymous and dispersed Christians, do not have the energy any more for constantly gathering the population for a common cult ${ }^{6}$.

${ }^{3}$ Gheorghios D. Metallinos, Parohia - Hristos in mijlocul nostru, Romanian translation Ioan I. Ică, Sibiu, Deisis Publishing House, 2004, p. 10.

${ }_{5}^{4}$ Ibidem, pp. 12-13.

5 Sergio Lanza, La parrocchia in un mondo che cambia, Situazioni $e$ prospettive, Roma, Edizioni OCD, 2003, pp. 225-226.

${ }^{6}$ Ion Bria, Curs de Teologie şi practică misionară ortodoxă, Geneva: Consiliul Ecumenic al Bisericilor (CEB), 1982, p. 78. 
In the parishes in the great cities, with thousands of believers, people participate to the Eucharist in absolute anonymity and loneliness. Each person in the Church is unknown among other unknown people, more than at the cinema, theatre, concert, or on stadiums. One prays or meditates alone, without sharing anything with those around, and anxiously waits for the communion with bread and wine, making sure one receives the body and blood of Christ from the hands of a servant with whom one does not have even a formal daily relation, just as one has never exchanged a single greeting with any of those who receive communion from the same chalice before or after him/her ${ }^{7}$.

The inhabitants of the big urban centres today are largely only nominal citizens. Established by social and professional conventions, they do not belong body and soul to their residential area or city, and the believers do not have the profound sentiment of belonging to a parochial community. Many of them do not even know their priest or, even worse, there are many priests who do not know their believers ${ }^{8}$. This is a consequence of the mammoth parishes disappearing in their gigantism, since they lack the possibility to function as dynamic communities. That is why a reform of the parishes, on a limited numeric basis, is the fundamental need for our times. The obvious sign of the religious drama in the urban area is the great anonymity in which all human relations are developed, and especially the pastoral-religious ones. We baptise nobody's children (we find the name of the parents and godparents from the papers), we join in holy matrimony anonymous young people (we read their names several times in the marriage certificate to make sure we know them during the ceremony), and we perform

Christos Yannaras, Contra Religiei, Romanian translation Tudor Dinu, București, Anastasia Publishing House, 2011, p. 146.

${ }^{8}$ Valer Bel, Misiune, parohie, pastorație, Cluj Napoca, Renaşterea Publishing House, 2006, p. 15.

${ }^{9}$ Gheorghios D. Metallinos, op. cit., p. 155. 
the burial rite for the dead by reading their name and age on the $\operatorname{cross}^{10}$.

Due to the great number of believers, the parish becomes incontrollable. The number of believers is no longer determined by the objective of establishing a community, but by that of fulfilling the individual religious needs. To serve these thousands of believers, a priest is not sufficient. A parish adds a second priest and a third, producing a team of priests. So the objective of having an ecclesial corpus with a single pastor completely disappears, because the Eucharist is no more fulfilled by the same priest in the same church. The Roman- Catholic Church was the first to lose the conscience and the reality of the parish, accepting multiple, successive celebrations of the Eucharist during the same day in the same church. Along with the increasing urbanisation, the Orthodox churches have hurried into imitation. Thus, the parish becomes, in the conscience of the believers, just a branch or an extension of a religious institution that provides quantitatively sufficient services ${ }^{11}$.

The consequence of the current situation is the fact that many believers search for a kind of presence of the Church without a parish, resulting in a deviation to a private, non-liturgical religion, and in the end, to the most severe form of distortion of the Christian faith, namely religious indifference.

Due to this situation, a formula must be found for the Eucharistic Liturgy of the parish to be extended also beyond the building of the church and the physical limits of the parish. This concept has been defined, in the Eastern theology and spirituality, as The Liturgy after the Liturgy ${ }^{12}$. Each believer is called to continue a personal liturgy, on the secret altar of his own heart, enacting a living proclamation of the good news for the entire world. Without this continuation, the Liturgy remains incomplete and inefficient. The Eucharistic sacrifice must be extended through our personal sacrifice

${ }^{10}$ Ion Buga, Pastorala - Calea Preotului, București, Publishing House: Sfântul Gheorghe - Vechi, 1999, pp. 142-143.

${ }^{11}$ Christos Yannaras, op. cit., pp. 145-146.

${ }^{12}$ Ion Bria, Regenerarea misiunii creştine în contextul urban,..., pp. 41-42. 
for those in need, for our brethren for whom Christ gave His Own life. The Extension of the Liturgy to life means a continuous attempt to shake off the power of evil which are working in us; it means a continuous reorientation and opening towards intuitions and efforts meant to free human persons from all the demonic structures of injustice, exploitation, agony, loneliness, and to the creation of a communion of persons within love ${ }^{13}$.

The life of the parish must be filled with the specific dynamic of the Liturgy. This dynamic has two movements: one is centripetal, the gathering of the community around the divine cult; the other is centrifugal, sending out the community into the world: Let us exit with peace! In the name of God! The liturgical life and the pastoral practice are two works that move the parish in its missionary becoming. ${ }^{14}$.

A synergic action between clerics and laics must be born within the parish. ${ }^{15}$ Faith is the one that achieves the true and more and more intense communion between the clergy and the laity. Inside the parochial community - a privileged place of this communion, a space consecrated by God forsalvation - the reality of the world may be truly transformed, and the social relations may be truly changed. Thus, it is essential for the Christian faith that the members of the parochial community should not live isolated, but united, forming a common body. Thus, they shall be able to combine their gifts and possibilities, to submit their entire life to the Kingdom of God already present, to accept the gift of the unanimity of agape. And only thus shall the parochial community truly become the place

\footnotetext{
${ }^{13}$ Anastasie Yannoulatos, Misiune pe urmele hi Hristos, Romanian translation $\square$ tefan L. Toma, Sibiu, Publishing House: Andreiană, 2013, pp. 112-113.

${ }^{14}$ Ioan Ică, Importanţa parohiei pentru misiune. Unitatea dintre parohie şi Biserica locală, unitatea internă a parohiei, mijloace şi metode de mentinere a acesteia, in "Pastorație și misiune în Biserica Ortodoxă", Galați, Publishing House: Episcopia Dunării de Jos, 2001, p. 25.

${ }^{15}$ Antonio Ruccia, Parrocchia e Comunità, Edizioni Dehoniane Bologna, 2007, p. 79.
} 
where the messianic sigs promised to the people of God will be able to shine and manifest their efficiency. ${ }^{16}$

The parish, in order to evangelise, must assume more and more the role of a Boundary Church ${ }^{17}$ It needs to step forward: from a Mass Church, to a Community Church. The mass church is addressing a zone constituted from those calling themselves, in a way or another, believers, but without getting consistently involved in the life of the parish. On the other hand, the community church aims to achieve, in specific notes, the free adhesion to faith, understood as a style of relations, under the sign of a brotherhood devoid of constraints and free from any structure of domination. Thus, it is proposed for the Church to become a place of Christian liberty and human

Thus, in the current context, the most stringent pastoral and missionary problem is to re-establish the integrity of the parish, geographically dispersed, and demographically and culturally complex, and to strengthen the conscience of belonging to a common body. The consolidation of the unity and life of the parish involves the renewal of the existing missionary and pastoral means, but also the creation of new pastoral forms ${ }^{18}$.

\section{The identity of the priest in the urban parochial community}

The identity of the priest within the community is shown by his sacrifice and his serving. The priest in the parish is called to equally assume the service and the sacrifice, which are his real identity in front of the believers. The first is the last of all, and the

\footnotetext{
${ }^{16}$ Gerhard Lohfink, Dio ha bisogno della Chiesa?Sulla teologia del popolo di Dio, Milano, Edizioni San Paolo, 1999, p. 301.

${ }^{17}$ Antonio Ruccia, op. cit., p. 80.

${ }^{18}$ Ion Bria, Curs de Teologie şi practică misionară,..., p. 79.
} 
servant to all, i.e. he is the first in humbleness and practice of disinterested love ${ }^{19}$.

The moral authority and the spiritual credit with which the priest is invested are very important for the success of his mission. The paternalistic pastoral is ineffective and irresponsible, not only because the priest needs the involvement of the laity in the activities of the Church, but also because this type of pastoral undermines the fundament of the community, destroying the spiritual communion between its believers. The priest is not a service provider or a public relations agent; he is the Christic image of the Church of Christ in the world. The Church is part of society, and the priest must involve the entire social body of the parish in a common work ${ }^{20}$.

The Church always lives and moves in the society, but within the persons of her believers, she strives not to be of the society, not to take its form. If the parish communicates with the world, and its members move in a wider worldly society, it follows that its life and activity cannot be limited inside the walls of the church, but must naturally extend to the entire space of society ${ }^{21}$.

The priest must maintain and permanently strengthen the spiritual integrity of the parish. In the parochial space there should not be peripheral circles of believers. It is well known that the victims of proselytism are recruited by sects from among those marginalised on different grounds. Although the Church possesses the entire truth, some believers are looking outside for things they think they cannot find in the parochial activity, not only in terms of human environment, but also in terms of express spiritual engagement, and especially in terms of concrete exercise of particular charismas. That is why the parochial lifestyle, pastoral discipline, and the coordination by the priest of a variety of gifts and service plays a decisive role ${ }^{22}$.

19 Giorgios I. Mantzaridis, Morala Creştină, vol. II, Publishing House: Bizantină, Bucureşti, 2006, p. 119.

${ }^{20}$ Ion Bria, Regenerarea misiunii creştine în contextul urban,..., p. 43.

${ }^{21}$ Gheorghios D. Metallinos, op. cit., p. 81.

${ }^{22}$ Ion Bria, Curs de Teologie şi practică misionară,..., pp. 80-81. 
The priest, along with the faithful in his parish, works for their salvation. From a missionary point of view, there is no separation between the work of the priest and the work of the believers, between the Church and the world. The Church, only in its unitary structure, hierarchy and the laity, is capable to lead the people to the final salvation. The problem, however, remains at the level of the contact between the priests and the lay community, the contact between the man of the Church and the man of God. The priest must step down among the people, consider himself one of them, as Christ stepped down into the world as a Human Being. The communion of its servants with the religious people is very important for the mission of the Church. This gives the Church wings for her infinite aspirations, so that the communion becomes much more profound, and, for the lay faithful, the priest becomes the yeast for the leaven ${ }^{23}$.

The continuous theological training of the priests in the cities (through conferences, courses, pastoral publications) is an essential necessity. The greatest drama for a priest as a theologian is to spread a false image of God, to associate the salvation offered by Jesus Christ with popular beliefs, mentalities, superstitions and customs lacking any theological fundament. Likewise, the ecumenical education of priests, especially in cities where confessional differences are aggravated by ethnical and cultural tensions, must be seriously provisioned in the courses of the theological schools ${ }^{24}$.

\section{The transmission of the word of God through homily and catechesis}

A special attention must be granted to the manner in which the priest talks about God. The urban parish is facing not only the problem of the theological language and the manner of carrying on the divine service, but also the issue of knowing, understanding and

\footnotetext{
${ }^{23}$ Mihai Himcinschi, Misiune şi dialog - Ontologia misionară a Bisericii din perspectiva dialogului interreligios, Alba Iulia, Reîntregirea Publishing House, 2003 , p. 33.

${ }^{24}$ Ion Bria, Regenerarea misiunii crestine în contextul urban, pp. 43-44.
} 
communicating God in contemporary society ${ }^{25}$. The authentic homily transforms people. It must combine a solid biblical answer with illustrative material and personal charisma in order to influence the listeners at their deepest level of understanding and motivation, if not even to truly change their lives ${ }^{26}$.

The priest is, par excellence, a servant of the word, and not preaching would mean an annulment of his own serving. If preaching the word of God has always been a fundamental element in the activity of priests in all epochs, today, more than ever, it is imperative for this activity to be an aspect where the priest should concentrate his entire exactness. The word of the priest, uttered loudly and wisely, is the visible sign that the Church is alive. The entire world is founded on the word of God, and the life of the parish is established on the word of the priest. The dedicated time of the homily is the Holy Liturgy, as integrant part of the Liturgy, showing that the homily has both a didactic, and a sacramental power. The homily during the Liturgy transforms and raises the hearts of the faithful. The Holy Liturgy is not just a sacrament of communion, but also a sacrament of the word. All the Christian priests and catechists state that the centre of the primary religious life was the homily and the breaking of bread;today, as in the past, the sanctification work must also come together with that of enlightening the faithful through the homily. Apart from the liturgical homily, mentioned above, the priest has the duty to use any moment in order to enlighten people about the faith ${ }^{27}$. Father Ion Buga, paraphrasing a patristic apothegm about prayer, affirms that the priest who preaches only when he preaches, in fact does not preach ${ }^{28}$.

According to the homiletical rules, the sermon must be addressed to all the faithful who are present in the church, as an

${ }^{25}$ Ibidem, p. 40.

${ }^{26}$ Joseph J. Allen, Slujirea Bisericii - chip al grijii pastorale, Romanian translation by Irineu Pop-Bistrițeanul, Cluj-Napoca, Renașterea Publishing House, 2010, p. 168.

${ }^{27}$ Ion Buga, op. cit., pp. 162-164.

${ }^{28}$ Ibidem, p. 164. 
essential means of collective pastoral. The homily gives a good guidance and a systematic collective pastoral of the believers in the parish $^{29}$

The preaching priest must fulfil some homiletic conditions. Firstly, the preacher must know the Gospel. Secondly, the proclamation of the Word cannot be separated from the concern for the community. Serving the word is the central part of the pastoral service. This may be observed in the context of nowadays parishes: if a religious person listens to a homily and then leaves the Liturgy wondering: "What is the connection between the homily and my Christian life?", then we should also wonder if the homily was good or not, if the Gospel has been properly preached, or if that person has received an appropriate pastoral care. The connection is obvious: the sermon is a part of the pastoral concern, because it represents a word powerfully uttered by the preacher, with the aim of changing or influencing the auditory. The principle of pastoral care is similar, even under different forms ${ }^{30}$.

\section{Conclusions}

The contemporary parish is called upon to recall the example that Christ left as a commandment to his apostles: "ye also ought to wash one another's feet. For I have given you an example that ye should do as I have done to you." (John 13.14 - 15) and "And whosoever will be chief among you, let him be your servant" (Matthew 20.27).

The parish must function for the benefit of the people: it must not settle for a small group and [...] is not the recipient of small communities, but the reference point and the place of concrete ecclesiastic confirmation. [...] It lives the season of hardships and of renewal as a Kairos. It picks it up as a precious opportunity for

\footnotetext{
${ }^{29}$ Spiridon Cândea, Studii şi articole de Pastorație Ortodoxă, Sibiu, Publishing House: Arhiepiscopia Sibiului, 2002, pp. 110-111.

${ }^{30}$ Joseph J. Allen, op.cit., pp. 167-168.
} 
activating a communion practice of researching and experiencing new models; it comes forth as a community of listening and projection; it discovers and values, from this perspective, gifts and competences that it has inside and were still not discovered. It does not bow, nor does it submit, but lives with hope the time of seeding. ${ }^{31}$

From a missionary point of view, one of the present-day problems is that the postmodern society declares that it does not need Christ and the Church. The personal religion is a private business, but with no big importance for the society. The mission, in an Orthodox perspective, upholds the value of the human being, which needs to be integrated in the communion of the Church of Christ. Still, the parochial community has the sense of the present history, and is at the same time capable of proposing and building new perspectives regarding the future of the Church in contemporary society.

From a pastoral point of view, it is necessary to reaffirm the centrality of the parish, i.e. the gathering of the faithful on every Sunday and every holiday to celebratethe Holy Liturgy. The parish is the sacred space for welcoming and dispatching its believers, who receive the Eucharistic Christ during the Liturgy, so as, thereafter, to herald Him and to give witness about Him to the whole world.

\section{Bibliography:}

1. Allen, Joseph J., Slujirea Bisericii - chip al grijii pastorale, Romanian translation by Irineu Pop-Bistrițeanul, Cluj-Napoca, Renașterea Publishing House, 2010.

2. Bel, Valer, Misiune, parohie, pastorație, Cluj Napoca, Renașterea Publishing House, 2006.

3. Bria, Ion, Curs de Teologie şi practică misionară ortodoxă, Geneva: Consiliul Ecumenic al Bisericilor (CEB), 1982.

${ }^{31}$ Sergio Lanza, Le conversioni pastorali richieste dalle attuazioni delle unità pastorali, in „Orientamenti Pastorali”, 7-8, 1999, p. 57. 
4. Bria, Ion, Regenerarea misiunii creștine în contextul urban, in "Relevanța operei Părintelui Profesor Ion Bria pentru viața bisericească și socială actuală”, Sibiu, Publishing House: Universitatea „Lucian Blaga”, 2010.

5. Buga, Ion, Pastorala - Calea Preotului, București, Publishing House: Sfântul Gheorghe-Vechi, 1999.

6. Cândea, Spiridon, Studii şi articole de Pastorație Ortodoxă, Sibiu, Publishing House: Arhiepiscopia Sibiului, 2002.

7. Himcinschi, Mihai, Misiune şi dialog - Ontologia misionară a Bisericii din perspectiva dialogului interreligios, Alba Iulia, Reîntregirea Publishing House, 2003.

8. Ică, Ioan jr., Misiune şi mărturie creştină faţă de prozelitismul religios care este o contramărturie creştină, in "Pastorație și misiune în Biserica Ortodoxă", Galați, Publishing House: Episcopia Dunării de Jos, 2001.

9. Ică, Ioan, Importanța parohiei pentru misiune. Unitatea dintre parohie şi Biserica locală, unitatea internă a parohiei, mijloace şi metode de menținere a acesteia, in "Pastoraţie şi misiune în Biserica Ortodoxă", Galați, Publishing House: Episcopia Dunării de Jos, 2001.

10. Lanza, Sergio, La parrocchia in un mondo che cambia, Situazioni e prospettive, Roma, Edizioni OCD, 2003.

11. Lanza, Sergio, Le conversioni pastorali richieste dalle attuazioni delle unità pastorali, in „Orientamenti Pastorali”, 7-8, 1999, p. 57.

12. Lohfink, Gerhard, Dio ha bisogno della Chiesa? Sulla teologia del popolo di Dio, Milano, Edizioni San Paolo, 1999.

13. Mantzaridis, Giorgios I., Morala Creştină, vol. II, Bucureşti, Publishing House: Bizantină, 2006.

14. Metallinos, Gheorghios D., Parohia - Hristos in mijlocul nostru, Romanian translation Ioan I. Ică, Sibiu, Deisis Publishing House, 2004.

15. Ruccia, Antonio, Parrocchia e Comunità, Edizioni Dehoniane Bologna, 2007.

16. Seveso, Bruno, L'ambito della comunità, in "Progetto pastorale e cura della fede", Edizioni Glossa, Milano, 1996.

17. Yannaras, Christos, Contra Religiei, Romanian translation Tudor Dinu, București, Anastasia Publishing House, 2011.

18. Yannoulatos, Anastasie, Misiune pe urmele lui Hristos, Romanian translation by Ştefan L. Toma, Sibiu, Publishing House: Andreiană, 2013. 